Jurnal PG-PAUD Trunojoyo : Jurnal Pendidikan dan Pembelajaran Anak Usia Dini, Volume 6, Nomor 2, Oktober 2019, hal 84 - 90, ISSN : 2528-3553 (online), ISSN: 2407-4454 (print)

\title{
PENGARUH PERMAINAN ANGKA TERHADAP KEMAMPUAN BERHITUNG PERMULAAN KELOMPOK B
}

\author{
Iin Khoirotul Masruroh \\ Dwi Nurhayati Adhani \\ Dewi Mayangsari \\ Program Studi Pendidikan Guru Pendidikan Anak Usia Dini \\ Universitas Trunojoyo Madura \\ Email: iinchocho19@gmail.com, adhaniuwi@gmail.com,mayangsarie@gmail.com
}

Received (Bulan Februari 2019), Accepted (Bulan Agustus 2019), Published (Bulan Oktober 2019)

\begin{abstract}
This study aims to find out how the influence of the numbers play on the initial numeracy ability of group B in Muslimat 03 Roudlotut Tholibin Kindergarten Warukulon. The subjects of this study were 14 children. This study uses a quantitative approach using an experimental method with a pre-experimental design of the Pretest-posttest-Design One-Group design. Data collection techniques used are observation and documentation. The data analysis technique is in the form of non-parametric statistics in the form of a Wilcoxon level test with data from the pretest and posttest assessment results. The results of this study were obtained at the pretest that there were 5 children with undeveloped criteria $(B B)$, and 8 children with criteria still developing $(M B)$, and 1children the criteria developed according to expectations (BSH). Whereas in the posttest study 3 children with criteria for excellent development (BSB), and 8 children with criteria developed according to expectations $(B S H)$, and there were 3 children with criteria still developing $(M B)$. The calculation result using the Wilcoxon level test obtained a value of Tcount $<$ Ttable $(0<21)$ that is T more than T table. So that the decision making is HO (Zero Hypotesis) is rejected and HA (Alternative Hypotesis) is accepted because Thitung < Ttable $(0<21)$. So that there is an influence on the numbers game on the initial numeracy skills at the Muslimat 03 kindergarten Roudlotut Tholibin Warukulon.
\end{abstract}

\section{Keywords: Number Game, Initial Counting Ability, Early Chilhood}

Abstrak: Penelitian ini bertujuan untuk mengetahui bagaimana pengaruh permainan angka terhadap kemampuan berhitung permulaan kelompok B di TK Muslimat 03 Roudlotut Tholibin Warukulon.Subjek penelitian ini adalah 14 anak.penelitian ini menggunakan pendekatan kuantitatif dengan menggunakan metode eksperimen dengaan desain pree-eksperiemental desainOne-Group Pretest-posttest-Design. Teknik pengumpulan data yang digunakan yaitu observasi dan dokumentasi. Teknik analisis data berupa statistik non parametrik berupa uji jenjang bertanda Wilcoxon dengan data hasil penilaian pretest dan posttest . hasil penelitian ini diperoleh pada saat pretest terdapat 5 anak dengan kriteria belum berkembang (BB), dan 7 anak dengan kriteria masih berkembang (MB), dan 2 anak kriteria berkembang sesuai harapan (BSH). Sedangkan pada penelitian posttest 3 anak dengan kriteria berekmbang sangat baik (BSB), dan 8 anak denga kriteria berkembang sesuai harapan (BSH), dan terdapat 3 anak dengan kriteria masih berkembang (MB).Hasil perhitungan dengan menggunakan uji jenjang Wilcoxon diperoleh nilai Thitung $<$ Ttabel $(0<21)$ yaitu Thitung lebih dari Ttabel.sehinggapengambilan keputusan yaitu HO (Hipotesis nihil) ditolak dan HA (Hipotesis alternativ)diterima karena Thitung <Ttabel $(0<$ 21). Sehingga diketahui bahwaada pengaruh permainan angka terhadap kemampuan berhitung permulaan di TK muslimat 03 Roudlotut Tholibin Warukulon.

Kata Kunci : Permainan Angka, Kemampuan Berhitung Permulaan, Anak Usia Dini

\section{PENDAHULUAN}

Pendidikan mempunyai peranan yang sangat penting dalam kehidupan manusia, terutama sejak anak lahir hingga dewasa. Untuk mengoptimalkan, dapat dikembangkan melalui usaha yang jelas dan terarah, yaitu melalui program Pendidikan Anak Usia Dini (PAUD). Berdasarkan Undang-undang No.2 Tahun 2003 tentang system Pendidikan Nasional, Bab 1 Pasal 1 butir 14, menyatakan bahwa Pendidikan Anak Usia Dini merupakan suatu upaya pembinaan yang ditunjukkan kepada anak sejak lahir sampai dengan enam tahun dengan pemberian rangsangan pendidikan untuk membantu pertumbuhan dan perkembangan jasmani rohani dalam memasuki pendidikan lebih lanjut (Suyadi, 2010:9). Oleh karena itu upaya pengarahan yang ditunjukkan kepada anak usia dini diharapkan dapat mengembangkan aspek perkembangan yang dimiliki anak sesuai dengan tahap perkembangannya.

Aspek perkembangan anak dalam mengembangkan sesuai dengan 
Jurnal PG-PAUD Trunojoyo : Jurnal Pendidikan dan Pembelajaran Anak Usia Dini, Volume 6, Nomor 2, Oktober 2019, hal 84 - 90, ISSN : 2528-3553 (online), ISSN: 2407-4454 (print)

perkembangannya salah satunya yaitu kemampuan kognitif. Kemampuan kognitif adalah salah satu kemampuan dari bidang pengembangan oleh guru untuk meningkatkan kemampuan dan kreativitas anak sesuai dengan tahap perkembangannya. Kemampuan kognitif merupakan suatu proses berfikir, yaitu kemampuan individu untuk menghubungkan, menilai dan mempertimbangkan suatu kejadian atau peristiwa (Jawati, 2013). Kemampuan kognitif adalah pikiran, melalui pikiran dapat digunakan dengan cepat dan tepat dalam memecahkan masalah. Menurut Peraturan Menteri Pendidikan Nasional Nomor 58 Tahun 2009 tentang Standar Tingkat Pencapaian Perkembangan Anak perkembangan kognitif anak usia 5-6 tahun mencakup 3 lingkup diantaranya yaitu belajar dan pemecahan masalah, berfikir logis, dan berfikir simbolik. Sehingga sudah seharusnya anak usia 5-6 tahun sudah mampu dalam kegiatan berhitung.

Salah satu lingkup perkembangan berfikir simbolik yang terdapat di Standar Tingkat Pencapaian Perkembangan Anak (STPPA) mencakup tentang bilangan dan huruf. Penggunaan bilangan pada Anak Usia Dini dalam mengembangkan kemampuan berhitung secara optimal. Menurut Susanto kemampuan berhitung permulaan adalah kemampuan yang dimiliki setiap anak untuk mengembangkan kemampuanya, karakteristik perkembanganya dimulai dari lingkungan yang terdekat dengan dirinya, sejalan dengan perkembangan kemampuanya anak dapat meningkat ke tahap pengertian mengenal jumlah yaitu pengurangan dan penjumlahan (Susanto, 2002: 98). Anak yang mampu dalam mengembangkan kemampuan kognitif dengan baik, anak mengenal konsep serta simbol bilangan, berhitung dengan baik sesuai dengan potensi yang mereka miliki dalam mengembangkan kemampuanya melalui permainan.

Terdapat banyak ragam permainan bagi Anak Usia Dini dalam melakukan kegiatan permainan diantaranya yaitu permainan angka, permainan huruf, permainan melalui gerak dan lagu, dan permainan kreatif. Permainan angka. Burns dalam bukunya Matc Solution dan Baratta Lorton dalam bukunya Math their Way keduanya mendasarkan pada teori Piaget yang menunjukkan bagaimana konsep matematika terbentuk pada anak. Burns mengatakan kelompok matematika yang sudah dapat diperkenalkan mulai dari usia tiga tahun adalah kelompok bilangan (aritmatika, berhitung), pola dan fungsinya, geometri, ukuran-ukuran, grafik, estimasi, probolitas, pemecahan masalah (Susanto, 2002: 161). Penggunaan permainan angka di TK Muslimat 03 Roudlotut Tholibin Warukulon menggunakan permainan kelereng.

Penggunaan permainan yang menarik dan menyenangkan akan mendukung proses belajar anak dalam mencapai aspek perkembangan yang dimilikinya. Permainan kelereng termasuk salah satu permainan rakyat yang sangat popular (Mulyani, 2016: 78). Anak akan mudah memahami simbol konsep angka. Cara penyampaianya menggunakan pengelihatan dan pendengaran yaitu dengan permainan kelereng. Kelereng merupakan alat permainan sebagai salah satu alat untuk berhitung yang mengembangkan kemampuan berhitung permulaan dan kognitif anak. Ketika anak bermain maupun belajar menggunakan kelereng dan guru melatih anak untuk mengenal simbol angka dan bilangan menggunakan kelereng, maka secara tidak langsung akan berkembang perkembangan kognitif anak.

Terdapat banyak perbincangan mengenai permasalahan didalam dunia pendidikan anak usia dini terutama dari segi pembelajaran yang belum maksimal, kesalahan-kesalahan kecil pendidik anak usia dini yang sering diremehkan serta kinerja para pendidik yang cenderung pasif dalam proses pembelajaran yang melahirkan konsep bahwa para pendidik kurang selektif dalam memilihkan permainan, para pendidik anak usia dini sering terpaku pada suatu kegiatan yaitu Lembar Kerja Anak (LKA) dan media yang sudah disediakan tanpa diiringi dengan permainan, metode atau strategi-strategi aktif yang membuat anak mempunyai minat belajar serta anak tidak bosan dalam proses pembelajaran, sehingga dari kesalahan-kesalahan tersebut menimbulkan beberapa permasalahan dalam kegiatan pembelajaran kemampuan berhitung rendah.

Berdasarkan permasalahan yang terjadi di TK Muslimat 03 Roudlotut Tholibin, sudah seharusnya para pendidik dan orang tua lebih kreatif dalam menyetujui akan adanya permainan yang akan dilakukan pada saat mengembangkan kemampuan anaknya. 
86 Jurnal PG-PAUD Trunojoyo : Jurnal Pendidikan dan Pembelajaran Anak Usia Dini, Volume 6, Nomor 2, Oktober 2019, hal 84 - 90, ISSN : 2528-3553 (online), ISSN: 2407-4454 (print)

Permainan yang digunakan disekolah adalah permainan kelereng dengan adanya anak akan berperilaku negatif dan anak akan terpaku permainan tersebut sehingga anak akan bermain bebas mungkin dengan temannya, serta dengan permainan angka yang sudah diterapkan pada proses belajar dilakukan pada saat kegiatan berhitung Seperti dengan menggunakan permainan kelereng dalam kemampuan berhitung anak disekolah anak akan mudah menerima.

Berdasarkan hasil observasi yang dilakukan peneliti pada 5 kali pertemuan, peneliti menemukan kegiatan dalam pembelajaran menggunakan permainan angka di TK Muslimat 03 Roudlotut Tholibin warukulon. Kegiatan proses pembelajaran dengan menggunakan permainan kelereng yang digunakan untuk menyampaikan materi kegiatan. Pada saat peneliti melakukan dengan pendidik terlihat ada masalah yaitu rendahnya anak dalam kemampuan hal ini terlihat dari seringnya anak salah dalam kegiatan berhitung 1-10. Misalkan guru bertanya kepada anak untuk berhitung kelereng yang diperolehnya dengan hasil 4 , anak berhitungnya mulai dengan hitungan 1, 2, 4, 5, 6. Serta anak kurang antusias dalam kegiatan berhitung. Didalam permainan terdapat pilihan kegiatan yang akan digunakan pendidik sesuai dengan rencana pembelajaran dan aspek perkembangan yang dicapai.

Pemahaman pendidik terhadap konsep menggunakan permainan angka menggunakan kelereng belum sesuai dengan apa yang diharapkan. Terdapat 14 anak yang kemampuan berhitung belum sesuai dengan tahap perkembangan dari jumlah keseluruhan anak kelompok B yaitu 14 anak.

Kegiatan berhitung menggunakan kelereng yang diterapkan di TK Muslimat 03 Roudlotut Tholibin Warukulon dalam mengembangkan kemampuan berhitung permulaan anak. Namun kegiatan bermain kelereng dilaksanakan dengan kegiatan permainan angka yang masih klasikal.

Berdasarkan dari hasil observasi lanjutan yang dilakukan oleh peneliti. Perkembangan kognitif anak masih belum berkembang sesuai dengan Standar Tingkat Pencapaian Perkembangan Anak. Seperti aspek perkembangan kognitif lingkup berfikir simbolik, membilang 1-10, dan mengenal lambang bilangan, menggunakan bilangan berhitung. Jadi, terdapat 14 anak yang kemampuan berhitungnya belum mampu sesuai dengan tahap perkembangan dari keseluruhan anak kelompok B yaitu 14 anak.

Berdasarkan permasalahan diatas, peneliti tertarik untuk mengetahui pengaruh permainan angka dengan kelereng terhadap kemampuan berhitung anak. Maka dari itu peneliti mengambil judul "Pengaruh Permainan Angka Terhadap Kemampuan Berhitung Permulaan Kelompok B di TK Muslimat 03 Roudlotut Tholibin Warukulon Pucuk Lamongan".

\section{METODE}

Penelitian ini menggunakan pendekatan penelitian jenis kuantitatif, yaitu pendekatan penelitian yang data penelitianya berupa angka-angka dan analisis datanya menggunakan statistika, sedangkan yang digunakan dalam penelitian ini menggunakan metode eksperimen. Desain penelitian ini menggunakan jenis pre-ekperimental one group pretest-posttest, karena penelitian ini menggunakan satu kelompok eksperimen. Fokus penelitian ini membandingkan kemampuan berhitung permulaan dalam proses pembelajaran sebelum diberikan pretest (sebelum ada treatment) dengan sebelum diberikan perlakuan (posttest).

Sampel penelitian yang diambil berjumlah 14 anak di kelompok B TK Muslimat Roudhotut Tholibin, dan nantinya akan diberikan pretest dan posttest untuk melihat hasil penelitian. Teknik pengumpulan data dapat melalui angket, wawancara), dokumentasi dan lainnya. Dalam melaksanakan pengamatan penelitian telah menyediakan lembar observasi penelitian yang telah teruji validitas dan realibilitasnya.

Penelitian ini menggunakan observasi terstruktur. Observasi terstruktur adalah observasi yang telah dirancang secara sistematis, tentang apa yang akan diamati, kapan dan dimana tempatnya (Riduwan, 2013: 203). Teknik pengumpulan data menggunakan pedoman observasi dengan daftar checklist dengan 4 opsi, yaitu 1) belum berkembang, 2) mulai berkembang, 3) berkembang sesuai harapan, 4) berkembang sangat baik.

$\begin{array}{ccc}\text { Pre-test } & \begin{array}{c}\text { Variabel } \\ \text { Terikat }\end{array} & \text { Post-Test } \\ \mathrm{O}_{1} & \mathrm{X} & \mathrm{O}_{2}\end{array}$

Gambar 1. Bagan Desain Penelitian 
Jurnal PG-PAUD Trunojoyo : Jurnal Pendidikan dan Pembelajaran Anak Usia Dini, Volume 6, Nomor 2, Oktober 2019, hal 84 - 90, ISSN : 2528-3553 (online), ISSN: 2407-4454 (print)

Dalam penelitian ini metode dokumentasi digunakan untuk mengetahui dan memperoleh data dalam penelitian saat di lapangan. Untuk mendukung proses dokumentasi maka diperlukan alat bantu seperti kamera dan buku catatan. Data penelitian tentang hal yang akan diteliti yaitu kemampuan berhitung permulaan pada kelompok B.

Teknik analisis dalam penelitian ini menggunakan statistik inferensial, parametris yang dilakukan dengan menggunakan uji-t, uji-t merupakan data yang digunakan yang berbentuk interval dan rasio yang berdistribussi normal untuk mengetahui signifikan hasil penelitian yang berupa variabel dari rata-rata sampel (Riduwan, 2011: 132). Sebelum melakukan uji t, terlebih dahulu dilakukan dengan ujui prasyarat untuk mengetahui data berdistribusi normal, linier, dan homogen.

\section{HASIL DAN PEMBAHASAN Hasil}

Pelaksanaan penelitian ini di TK Muslimat 03 Roudlotut Tholibin terdiri dari tiga tahapan penelitian yaitu, penelitian awal (pretest), tahap pemberian perlakuan (treatment), dan tahap penilaian setelah diberikan perlakuan (posttest). Untuk menjelaskan yang lebih lengkap, berikut tahapan pada pelaksanaan penelitian.

Pemberian perlakuan yang akan diberikan kepada anajk sesuai dengan renacana pembelakjaran atau RPPH yang telah dibuat dan disepakati oleh guru kelas dan peneliti serta ijin kepala sekolah. Treatment dilakukan (satu) kali pertemuan. Tahap pemberian perlakuan yang dilakukan pada hari Sabtu tanggal 29 September 2018.

Adapaun kegiatan denagn menggunakan pendekatan secara langsung yang dilakukan oleh guru untuk memberikan perlakuan pada anak tentang penjelasan kegiatan yang akan dilakukan serta cara, kegiatan yang dilakukan yaitu dijelaskan terlebihb dahulu dabn dilanjutkan dengan praktik. Tujuan kegiatan ini adalah untuk mengetahui kemampuan anak dlalam kegiatan yaitu meliputi menyebutkan angka, membilang dengan benda, dan mengurutkan lambang bilangan.
Tabel 1 .

Hasil Rata-rata (Pretest)

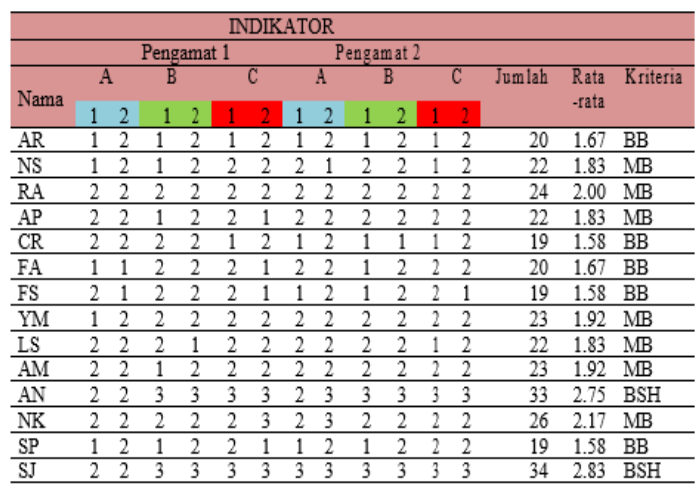

Tabel 2.

Hasil rata-rata (Postest)

\begin{tabular}{lllllllllllllllll}
\hline \multicolumn{10}{c}{ Pengamat 1 } & \multicolumn{10}{c}{ Pengamat 2 } \\
\hline Nama & A & B & C & A & B & C & Jumlah & Rata- & Kriteria \\
& 1 & 2 & 1 & 2 & 1 & 2 & 1 & 2 & 1 & 2 & 1 & 2 & & rata & \\
\hline AR & 2 & 3 & 2 & 2 & 2 & 2 & 2 & 2 & 3 & 2 & 3 & 3 & 29 & 2.42 & MB \\
NS & 2 & 2 & 3 & 3 & 3 & 3 & 3 & 2 & 4 & 3 & 3 & 2 & 33 & 2.75 & B SH \\
RA & 2 & 2 & 2 & 3 & 2 & 2 & 3 & 2 & 3 & 3 & 2 & 3 & 29 & 2.42 & MB \\
AP & 3 & 3 & 2 & 3 & 3 & 3 & 2 & 3 & 3 & 3 & 3 & 3 & 34 & 2.83 & B SH \\
CR & 3 & 3 & 2 & 2 & 3 & 3 & 3 & 2 & 3 & 3 & 2 & 3 & 32 & 2.67 & B SH \\
FA & 2 & 2 & 2 & 3 & 3 & 3 & 3 & 2 & 3 & 2 & 3 & 3 & 31 & 2.58 & BSH \\
FS & 2 & 3 & 3 & 2 & 3 & 3 & 3 & 3 & 2 & 3 & 3 & 3 & 33 & 2.75 & BSH \\
YM & 3 & 3 & 2 & 3 & 2 & 4 & 3 & 3 & 3 & 3 & 3 & 3 & 35 & 2.92 & BSH \\
LS & 3 & 4 & 3 & 4 & 4 & 3 & 3 & 3 & 4 & 3 & 4 & 3 & 41 & 3.42 & BSB \\
AM & 3 & 2 & 3 & 3 & 3 & 2 & 3 & 2 & 2 & 3 & 3 & 2 & 31 & 2.58 & BSH \\
AN & 4 & 3 & 4 & 4 & 3 & 3 & 3 & 4 & 4 & 3 & 3 & 3 & 41 & 3.42 & BSB \\
NK & 3 & 2 & 3 & 3 & 2 & 3 & 2 & 3 & 4 & 3 & 3 & 3 & 34 & 2.83 & BSH \\
SP & 2 & 4 & 3 & 2 & 2 & 2 & 3 & 3 & 2 & 2 & 3 & 2 & 30 & 2.50 & MB \\
SJ & 4 & 3 & 3 & 4 & 3 & 4 & 3 & 3 & 3 & 4 & 4 & 4 & 42 & 3.50 & BSB \\
\hline
\end{tabular}

Data hasil pretest diperoleh dari penilaian pengamat 1 dan pengamat 2 akan ditampilkan pada tabel 1. Berdasarkan hasil dari pretest dan posttest pada tabel 1 diperoleh hasil yang diuraikan dari masing-masing anak, diantaranya dari 14 anak terdapat 5 anak yang masuk dalam kategori BB (belum berkembang) yakni AR dengan nilai rata-rata 1,67, CR dengan nilai rata-rata 1,58, FA dengan nilai rata-rata 1,67 , FS dengan nilai rata-rata 1,58, SP dengan nilai rata-rata 1,58. Terdapat 7 anak yang masuk dalam kategori MB (Masih Berkembang) yaitu NS dengan nilai rata-rata 1,83 , RA dengan nilai rata-rata 2,00, AP dengan nilai rata-rata 1,83, YM dengan nilai rata-rata 1,92 , LS dengan nilai rata-rata 1,83, AM dengan nilai rata-rata 1,92, NK dengan nilai rata-rata 2,17,. dan terdapat 2 anak yang tergolong dalam kategori berkembang sesuai harapan (BSH) yaitu $\mathrm{AN}$ dengan nilai rata-rata 2,75 SJ dengan nilai rata-rata 2.83 .

Data posstest dilakukan selama satu haru, setelah mendapatkan perlakuan dengan memberikan kegiatan berhitung permulaan anak. Berdasarkan hasil observasi observer 1 
88 Jurnal PG-PAUD Trunojoyo : Jurnal Pendidikan dan Pembelajaran Anak Usia Dini, Volume 6, Nomor 2, Oktober 2019, hal 84 - 90, ISSN : 2528-3553 (online), ISSN: 2407-4454 (print)

dan observer 2 dapat diperoleh hasil pada tabel 2.

Tabel 3.

Rekapitulasi Hasil Observasi Pretest dan

Posttest dalam Kemampuan Berhitung

Kelompok B di TK Muslimat 03 Roudlotut

Tholibin

\begin{tabular}{ccccc}
\hline No. & Nama & Pretest & Posttest & Skor Kenaikan \\
\hline 1. & AR & 1.58 & 2.42 & 0.83 \\
\hline 2. & NS & 1.58 & 2.42 & 0.83 \\
\hline 3. & RA & 1.58 & 2.50 & 0.92 \\
\hline 4. & AP & 1.67 & 2.58 & 0.92 \\
\hline 5. & CR & 1.67 & 2.58 & 0.92 \\
\hline 6. & FA & 1.83 & 2.67 & 0.83 \\
\hline 7. & FS & 1.83 & 2.75 & 0.92 \\
\hline 8. & TM & 1.83 & 2.75 & 0.92 \\
\hline 9. & LS & 1.92 & 2.83 & 0.92 \\
\hline 10 & AM & 1.92 & 2.83 & 0.92 \\
\hline 11. & AN & 2.00 & 2.92 & 0.92 \\
\hline 12. & NK & 2.17 & 3.42 & 1.25 \\
\hline 13. & SP & 2.75 & 3.42 & 0.67 \\
\hline 14. & SI & 2.83 & 2.50 & 0.67 \\
\hline
\end{tabular}

Tabel 4.

Hasil Uji Wilcoxon

\begin{tabular}{llclcccc}
\hline No. Nama & $\begin{array}{l}\text { Pretest } \\
\text { (Xa1) }\end{array}$ & $\begin{array}{l}\text { Posttest } \\
\text { (Xb1) }\end{array}$ & $\begin{array}{l}\text { Bed A } \\
\text { (Xb1- } \\
\text { Xa-1) }\end{array}$ & \multicolumn{3}{c}{ Tanda Jenjang } \\
Jenjang & + & - \\
\hline 2. & AR & 1.67 & 2.42 & 0.75 & 9 & 9 & 0.00 \\
\hline 3. & RS & 1.83 & 2.75 & 0.92 & 7 & 7 & 0.00 \\
\hline 4. & AP & 1.83 & 2.83 & 1.00 & 4.5 & 4.5 & 0.00 \\
\hline 5. & CR & 1.58 & 2.67 & 1.08 & 3 & 3 & 0.00 \\
\hline 6. & FA & 1.67 & 2.58 & 0.92 & 7 & 7 & 0.00 \\
\hline 7. & FS & 1.58 & 2.75 & 1.17 & 2 & 2 & 0.00 \\
\hline 8. & YM & 1.92 & 2.92 & 1.00 & 4.5 & 4.5 & 0.00 \\
\hline 9. & LS & 1.83 & 3.42 & 1.58 & 1 & 1 & 0.00 \\
\hline 10. & AM & 1.92 & 2.58 & 0.67 & 11.5 & 11.5 & 0.00 \\
\hline 11. & AN & 2.75 & 3.42 & 0.67 & 11.5 & 11.5 & 0.00 \\
\hline 12. & NK & 2.17 & 2.83 & 0.67 & 11.5 & 11.5 & 0.00 \\
\hline 13. & SP & 1.58 & 2.50 & 0.92 & 7 & 7 & 0.00 \\
\hline 14 & SJ & 2.83 & 3.50 & 0.67 & 11.5 & 11.5 & 0.00 \\
\hline$\Sigma$ & & & & & & 92 & T=0 \\
\hline
\end{tabular}

Berdasarkan hasil data nilai posttest pada tabel 2 diperoleh hasil yang diuraikan dari masing-masing anak, diantarnya dari 14 anak terdapat 8 anak yang masuk dalam kategori BSH (berkembang sesuai harapan) yakni NS dengan nilai rata-rata 2,75, AP dengan nilai rata-rata 2,83, CR dengan nilai rata-rata 2,67, FA dengan nilai rata-rata 2,68, FS dengan nilai rata-rata 2,75, YM dengan nilai rata-rata 2,92, AM dengan nilai rata-rata 2,58 , NK dengan nilai rata-rata 2,83 . Terdapat pula 3 anak yang masuk dalam kategori BSB (berkembang sangat baik) yaitu LS dengan nilai rata-rata 3,42 , AN dengan nilai rata-rata 3,42 , SJ dengan nilai rata-rata 3,50. Terdapat 3 anak yang masuk dalam kategori MB (masih berkembang) yaitu AR dengan nilai rata-rata 2,42 , RA dengan nilai rata-rata 2,42, SP dengan nilai rata-rata 2,50.

Berdasarkan hasil penelitian yang dilakukan oleh peneliti dari hasil pretest dan posttest dapat dilihat dari hasil skor antara pretest dan posttest pada tabel 3 .

Kemampuan anak dalam berhitung benda sebelum diberikan treatment secara keseluruhan 5 (BB) dengan rata-rata 1,00-1,75 dan terdapat 7 anak (MB) dengan nilai ratarata 1,76-2,50, terdapat 2 anak (BSH) dengan selisih kenaikannya. Pada kegaitan pretest anak belum mencapai nilai tergolong berkembang sangat baik (BSB). Akan tetapi setelah diberikan treatment terdapat 5 anak mengalaim perubahan yang awalnya masuk dalam kategori belum berkembang (BB) dan mulai berkembang (MB) sehingga mereka menjadi kategori berkembang sesuai harapan (BSH) dengan rata-rata 2,51-3,25. Serta terdapat 5 anak yang awalnya masuk kategori belum berkembang (BB) dan mulai berkembang (MB) sehingga mereka menjadi kategori berkembang sanagt baik (BSB) dengan rata-rata kenaikan 3,26-4,00.

Pengujian hipotesis pada penelitian ini yaitu untuk mengetahui apakah ada pengaruh atau tidak saat diterapkan permainan yaitu dengan permainan angka terhapa kemampuan berhitung permulaan anak dalam kelompok B di TK Muslimat 03 Roudlotut Tholibin desa Warukulon kecamatan pucuk kabupaten lamongan. Pada penelitian ini menggunakan uji non parametrik uji jenjang bertanda Wilcoxon.

Berdasarkan hasil perhitungan analisis data pada penelitian ini menggunakan uji jenjang bertanda Wilcoxon, dapat diketahui bahwa Thitung $<$ Ttabel $(0<21)$. Hal ini menunjukkan bahwa nilai 0 jauh dibawah 21 . Berdasarkan kriteria keputusan pada uji jenjang bertanda Wilcoxon, yang telah terpapar diatas terdapat hasil bahwa Ha ditolak, maka dapat disimpulkan bahwa Ha diterima. Hal ini berarti ada pengaruh antara permainan angka terhadap kamampuan berhitung permulaan kelompok B di TK Muslimat Roudlotut Tholibin Warukulon Kecamatan pucuk Kabupaten Lamongan. 
Jurnal PG-PAUD Trunojoyo : Jurnal Pendidikan dan Pembelajaran Anak Usia Dini, Volume 6, Nomor 2, Oktober 2019, hal 84 - 90, ISSN : 2528-3553 (online), ISSN: 2407-4454 (print)

\section{Pembahasan}

Berdasarkan data yang diperoleh melalui observasi dan sudah melalui hasil perhitungan uji hipotesis dapat diperoleh nilah bahwa nilai $<(0<21)$. Hal ini menunjukkan bahwa nilai 0 jauh dibawah 21. Berdasarkan kriteria keputusan pada uji jenjang bertanda Wilcoxon, yang telah terpapar diatas maka dapat disimpulkan bahwa Ha diterima, berarti ada pengaruh antara permainan angka terhadap kemampuan berhitung permulaan kelompok B di TK Muslimat 03 Roudlotut Tholibin Warukulon.

Adanya pengaruh permainan angak terhadap kemampuan berhitung permulaan kelompok B merupakan anak usia dini yang sedang menjalani suatu proses perkembangan dan pertumbuhan sangat pesat dan fundamental bagi kehidupan selanjutnya. Sejalan dengan pendapat Yuliani (dalam sujiono) bahwa anak usia dini merupakan sosok individu yang sedang menjalani suatu proses perekmabangan dengan pesat san fundamental bagi kehidupan anak (Sujiono, 2013: 6).

Berdasarkan penelitian yang telah dilakukan di TK Musliamat 03 Roudlotut Tholibin diperoleh data bahwa terdapat anak yang dikatagorikan dalam perkembangan kognitif khsusunya kemampuan dalam berhitung anak berada pada kategori belum berkembang dan mulai berkembang. Menurut Neisser dalam Muhibin Syah) mengatakan bahwa "cognitive" berasal dari kata cognition yang berarti mengetahui. Sedangkan dalam arti luas kognisi adalah perolehan, penataan, dan penggunaan pengetahuan (Syah, 2013: 65). Perkembangam kognitif dalam perkembangan menurut Jean Piaget terdapa empat tahap diantaranya yaitu, Sensori-motor, Praoprasional, Operasional konkrit, dan Operasional formal.

Berdasarkan subejk penelitian mengambil subjek anak kelompok B di mana anak berada pada tahap pra-oprasional konkrit (2-7 tahun). Pada masa ini anak membutuhkan bendabenda konkrit dalam kegiatan pembelajaran. Menurut Kurikulum 2004 Standart Kompetensi TK/RA bertujuan untuk mengenalkan dalam menggunakan hitungan. Pada usia ini di dalam pikiranya tidak didasarkan pada keputusan yang logis melainkan hanya dilihat seketika, perilaku yang dapat diamati pada perkembangan anak usia dini, antara lain menggunakan kata-kata dengan menggunakan kata-kata benda, menghitung secara sederhana (Susanto, 2011: 106).

Penelitian ini dilakukan di TK MUslimat 03 Roudlotut Tholibin desa Warukulon Kecamatan Pucuk Kabupaten Lamongan yaitu dengan permainan angka terhadap kemampuan berhitung permulaan kelompok B. kegiatan yang dilakukan adalah memberi kegiatan dengan permainan angka dengan kelereng. Mentossore menyatakan bahwa anak usia dini dini, suatu permainan sederhana seperti menghitung dengan jari maupun jari kakinya merupakan awal yang sangat baik, memanfaatkan segala sesuatu yang ada dilingkungan anak, seperti menghitung bendabenda yang ada disekitarnya, pepohonan disepanjang perumahan (Mutiah, 2010: 162). Hal ini akan merangsang kesadaran anak terhadap angka-angka. Sehingga angka-angka dipelajari sebagai rutinitas, maka anak akan terbiasa dengan hitung menghitung saat bermain.

Hal ini senada dengan pendapat Hurlock seiring dengan perekembangan pemahaman bilangan permulaan ini, menyatakan bahwa konsep yang dimulai dipahami anak sejalan dengan bertambahnya pengalaman yang dialami anak (Susanto, 2011: 107). Berdasarkan uraian diatas, maka program pengemabangan kemampuan berhitung permulaan di taman kanak-kanak memiliki tujuan untuk memperkenalkan anak dalam menggunakan hitungan. Materi tersebut terdapat dikurikulum 2004 Standar Kompetensi Taman Kanak-kanak, materi yang diberikan dianatarana: membilang, mneyebut urutan bilangan 1-20, membilang (mnegenal konsep bilangan dengan benda-benda) sampai 1-10, mengurut ururan bilangan 1-10 dengan benda-benda.

Berdasrkan paparan diatas keseluruhan hasil penelitian diatas dapat diketahui bahwa dengan permainan angka dapat berpengaruh terhadap kemampuan berhitung permulaan kelompok B di TK Muslimat 03 Roudlotut Tholibin desa warukulon kecamatan pucuk kabupaten Lamongan.

\section{SIMPULAN}

Dari hasil penelitian dapat disimpulkan bahwa ketika guru melakukan penerapan pembelajaran dengan menggunakan permainan 
90 Jurnal PG-PAUD Trunojoyo : Jurnal Pendidikan dan Pembelajaran Anak Usia Dini, Volume 6, Nomor 2, Oktober 2019, hal 84 - 90, ISSN : 2528-3553 (online), ISSN: 2407-4454 (print)

angka, maka anak akan mengalami kenaikan pada kemampuan berhitung anak kelompok B di TK Muslimat 03 Roudlotut Tholibin Warukulon. Berdasarkan hasil penelitian yang dilandaskan dengan teori-teori yang mendukung, dan dengan jenjang bertanda Wilcoxon dengan hasil yang telah terpapar diatas, maka dapat menjawab rumusan masalah bahwa ada pengaruh permainan angka terhadap kemampuan berhitung permulaan anak dikelompok B di TK Musliamt 03 Roudlotut Tholibin Warukulon.Bagian simpulan berisi temuan penelitian yang berupa jawaban atas pertanyaan penelitian atau berupa intisari hasil pembahasan.

\section{DAFTAR PUSTAKA}

Depdiknas. 2003. Undang-undang RI No.20 tahun 2003 tentang sistem pendidikan nasional.

Depdiknas. 2009. Peraturan Menteri Pendidikan Nasional Republik Indonesia Nomor 58 Tahun 2009 tentang Standar Pendidikan Anak Usia dini. (tidak diterbitkan).

Jawati, R. 2013. Peningkatan Kemampuan Kognitif Anak Melalui Permainan Ludo Geometri Di PAUD. Padang: Universitas Negri Padang.

Mulyani, N. 2016. Super Asyik Permainan Tradisional Anak Indonesia. Yogyakarta: Diva Press.

Mutiah, D. 2010. Psikolgi Bermain Anak Usia Dini. Jakarta: Prenada Media Group.

Riduwan. 2004. Belajar Mudah Penelitian Guru Karyawan Peneliti Pemula. Bandung: Alfabeta.

Sujiono, Y. dkk. 2013. Metode Pengembangan Kognitif . Banten: Universitas Terbuka.

Susanto, A. 2002. Perkembangan Anak Usia Dini. Cetakan ke-1. Jakarta: Kencana Predana.

Susanto, A. 2011. Perkembangan Anak Usia Dini Pengantar dalam Berbagai Aspeknya. Jakarta: Kencana.

Suyadi. 2010. Psikologi Belajar PAUD. (Cetakan ke-1). Yogyakarta; Pustaka Insan Madani.

Syah, M. 2013. Psikologi Pendidikan. Bandung: PT Remaja Rosdakarya. 